\title{
THE STRANGER AT THE FEAST: PROHIBITION AND MEDIATION IN AN ETHIOPIAN ORTHODOX CHRISTIAN COMMUNITY By Tom Boyleston
}

\author{
Reviewed by Harold Wanton
}

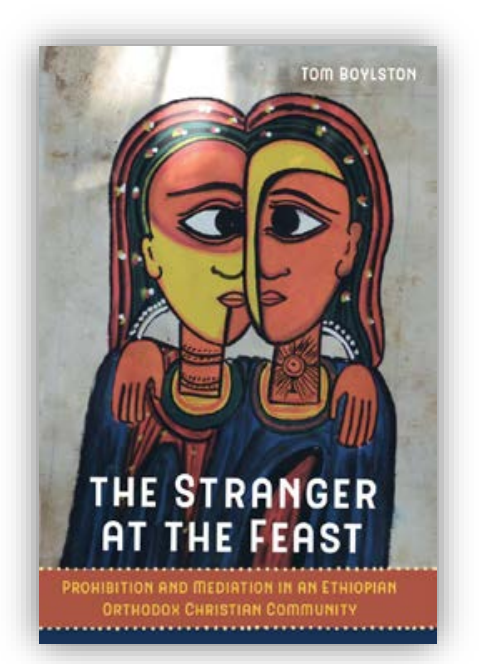

Berkeley: University of California Press 2018

In The Stranger at the Feast: Prohibition and Mediation in an Ethiopian Orthodox Christian Community, Tom Boylston blazes a new path for ethnography in Ethiopia in eloquent terms. Historically, anthropology was slow to develop in Ethiopia due to its link with colonial rule, but now ethnographers have been tasked with educating the public on the cultural richness of Ethiopia. Although "The Stranger at the Feast" is not overly historical, the ethnography delves into the sociohistorical significance of ritual prohibitions and their mediation among the inhabitants of Zegeña. Prohibitions in the Ethiopian society, specifically in Zegeña, date back to a covenant between God and a monk named Abune Betre Maryam. The covenant states that as long as no trees are cut, land ploughed, or large animals kept, the people of Zege would be protected from natural disasters and wild animal attacks. Thus ploughing, for example, is prohibited within the Ethiopian society, but prohibitions are always accompanied by mediations that can been observed in intrareligious events. Boylston depicts the interdependence of prohibitions and their mediations as, "Where there are rules and acts of avoidance, we see not just mediators, but proliferations of mediators" (12). The ethnography of Zegeña, a peninsular province in Ethiopia, provides a closer look at the observance of the Ethiopian Orthodox Church's organization in everyday life even after the secularization of the Ethiopian state. Boylston suggests that while the state has become secularized, Ethiopian Orthodox core principles of prohibition and mediation remain intact, if not enhanced, in Zegeña (3).

One strength of this work is Boylston's description of the intricacies of the Orthodox calendar and how it navigates fasting and feasting. While not all Ethiopians are Orthodox Christians, all adhere to the calendar in everyday life. Boylston not only describes the largescale religious change after the fall of Emperor Haile Selassie, but he meticulously highlights the local transformations in feeding practices, ritual prohibition, and hospitality. Boylston describes the special role that coffee plays in the Habesha community, which "shifts between hospitality medium, commodity item, and sacred tree" (83). Boylston has truly set the bar for ethnographic work in Ethiopia and has given anthropologists a fruitful foundation to build upon.

Boylston divides the book into an introduction and nine chapters. In each chapter, Boylston reconstructs the social history of Zege, describing the political and social entanglement of the relationship between monastic and political power. For instance, the Orthodox calendar is the most important mechanism of regulation of life in Ethiopia for everyone.

The Stranger at the Feast describes how Ethiopian culture has preserved religious traditions to the point that religion and culture are one. The reluctance to allow other religions to dominate socio-political roles and the common adherence to the Orthodox calendar and traditions have allowed Ethiopia to stand by its faith in a relentless manner, allowing all decisions, state and 
otherwise, to be done through the lens of the Orthodox Church.

A Christian anthropologist's perspective would engage Ethiopian culture and Ethiopian Orthodox Tawahedo tradition with both the heightened understanding of a Christian theological perspective and the ethnographic data of an anthropologist's view of the unique variations within Ethiopian culture. The Ethiopian Orthodox Tawahedo Church plays an important role in the whole of Ethiopian culture. The constant tension between religious prohibitions and political institutions require ongoing mediation. But the Orthodox tradition is interwoven into the cultural fabric of all Ethiopians. In this, the existence of a secularized state under the constant influence or guidance from religion presents ways in which Christianity and culture interact.

The Stranger at the Feast is a groundbreaking ethnographic study in that it is a study of one of the oldest Christian traditions. This text is particularly suitable for scholars, and it explores the complexities of both Ethiopian culture and Orthodox tradition. Professional scholars, anthropologists, economists, and linguists will benefit from this body of work, and it provides readers with a considerable understanding of one of the least-understood religious traditions and its influence within the contemporary secularized Ethiopian state.

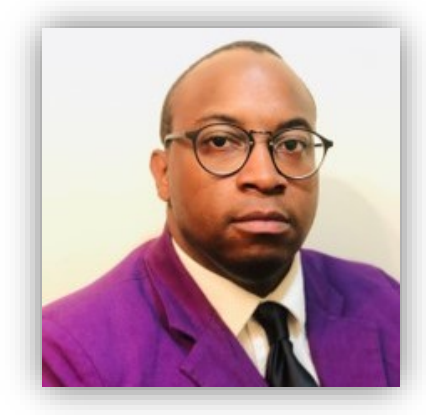

Harold Wanton is currently pursuing a master's degree in Theological and Cultural Anthropology at Eastern University, in St. David, Pa. He has research interests in religion, Ethiopian Orthodox Church and sociolinguistics.

Author email: harold.wanton@eastern.edu 